\title{
Schopenhauer'un Düşüncelerinde Bir Özgürleşme Olanağı Olarak Müzik
}

DOI: $10.26466 /$ opus.574104

\author{
$\underline{\text { R. Görkem Aytimur* }}$ \\ *Dr. Öğr. Üyesi, Tokat Gaziosmanpaşa Üniversitesi, Eğitim Fakültesi, Tokat / Türkiye \\ E-P osta: gorkemay timur@g mail.com \\ ORCID: $\underline{0000-0001-8389-1504}$
}

Öz

Bu çalışmada Schopenhauer'un düşüncelerinde özg ür eylemin müzik a racllığıyla olanakhllğ̆ı araştırllmıştrr. Schopenhauer'un felsefesinin temel kavramı olan isteme, varolan her şeyin değişmez özünü belirtmektedir. İstemenin yega ne a macı yaşamını sürdürmektir. Va rolan her şey de bu a maç doğrultusunda istemenin belirli ba sa maklardaki nesnelleşmesidir. İsteme görüngüler (fenomenler) dünyasında kendini açımlarken, uzay, zaman ve yeter sebep kalıplarila nesnelleşir. Tek tek varolan her şey, aynı zamanda istemenin kendisi olarak, nedensellik zincirinin bir parçasıdır ve kör bir dürtü olan isteme ta ra findan kuşa tılmıştır. Nedensellik özgür eylemi engellemektedir. Bir isteme doğ rultusunda özgürce hareket edildiği düşünülse bile, bu hep da ha önceye dayanan bir başka istemenin sonucu olarak ortay a çımaktadır Nedensellik zincirinin işleyişi bu şekildedir. Burada temel olan istemenin kendisinin bu nedensellik zincirinden ba ğ ımsız bir şekilde özg ür olup olmadı̆ğdır. Kör bir dürtü olan isteme ta rafindan kuşatılmış zorunlu bir nedensellik zinciri, özgür istemeyi engellemektedir. Çalışmanın bu bağlamında Schopenhauer'un düşüncelerinde özgür eylemin olanakllığı incelenmiş ve bu olanaklılı̆̆ın bir yolu olarak da müziğin doğası orta ya konulmuştur.

Anahtar Kelimeler: Schopenhauer, İsteme, Tasarm, Müzik, Özgürİrade. 


\title{
Music as a Possibility of Freedom in Schopenhauer's Thoughts
}

\begin{abstract}
In this study, Schopenhauer's thoughts expressed the possibility of free action through music. The "will" which is the basic concept of Schopenhauer's philosophy refers to the invariable essence of all things that exist. The only purpose of will is to live. Every thing exists is the objectivization of will in certain steps for this purpose. In the world of phenomenon, self-expla nations a re objectivized by space, time and sufficient rea son's forms. Every thing that is individually present is also part of the cha in of causality, as a will itself, and surrounded by a blind impulse. Causality is the obstacle of free action. One can think to move freely in the direction of a will but this is always the result of a nother will based on a previous one. This is the way how the causality chain works. The basis here is whether the request itself is independent of this chain of causality. A compulsory chain of causality surrounded by will, which is a blind impulse, prevents free will. In this context, the possibility of free action is examined in Schopenhauer's thoughts and the nature of music is put forward as a way of this event.
\end{abstract}

Keywords: Schopenhauer, Will, Representation, Music, Freewill 


\section{Giriş}

Schopenhauer'un felsefi düşüncelerinde özgür irade ve ona uygun eylemin olanağı önemli bir yer tutmaktadır. Felsefesinin temel yaklaşımı olan "isteme (istenç)" ontolojik bir öz olmanın yanında epistemolojik ve ahlaki bir ilkeyi de ifade etmektedir. Bu kavramsal çerçevede her şeyi kuşatıcı istemeye karşı, özgür eylem, irade veya arzunun olanağı, Schopenhauer'un düşünceleri bağlamında belirtilmiştir. Schopenhauer, isteme karşısında özgürlüğün olanağından söz ederken müziğin öneminden de söz etmektedir. Çalışmanın temel problemi Schopenhauer'un düşüncelerinde her şeyi kuşatan bir öz olan istemenin karşısında, özgür iradenin olanağının müzik yoluyla nasıl sağlanacağıdır. $\mathrm{Bu}$ problem doğrultusunda amaçlanan müzik sayesinde özgür irade olanağının açıklanmasıdır. Fakat bütün bu olanaklılı̆̆ı ifade etmeden önce, Schopenhauer'un istemeve tasarım olarak felsefi düşüncelerini nasıl yapılandırdığından söz etmek gerekmektedir.

Schopenhauer'un felsefesinin temelini dünyanın tasarım ve bu haliyle öznenin nesnesi olduğu düşüncesi oluşturur. Tasarım olarak dünya, hem bütününde, hem de parçaların da istemen in nesneleşmiş halidir. İstemen in nesne olması da temelde tasarım olması anlamı taşımaktadır. Schopenhauer'un felsefesindeki bu tasarım anlayışıyla, Kant'ın fenomennumen düşünceleri arasında bir bağ kurmak mümkündür. Fenomenler yani görüngüler (görünür olanlar) deney dünyasina ait ve duyularla algılanabilir olanlar olarak ifade edilir. Diğer taraftan numen ait olduğu şeyin değişmez gerçekliği (tözü) olarak belirtilir. Kant bu tözsel gerçekliğe "Kendinde Şey (Ding-an-Sich)" demiştir. Görüngüler ile kendinde şey ikircikliği (düalizmi) Schopenhauer'un düşüncelerinde "Tasarm (Vorstellung)" ve “İsteme (Wille)" olarak karşımıza çıkar. İsteme, tıpkı kendinde şey gibi, görüngülere ait bütün kurgulardan uzak, kör ve kuşatıcı bir tözü belirtmektedir. Oysa görünen ve duyularla algılanan bütün diğer şeyler, belirli kalıplarıyla yapılanmış tasarımlardır. İşte bu tasarımlar Schopenhauer'a göre uzay, zaman, nedensellik (yeter sebep) kalıplarıyla (Kant'a görekategorileriyle) sınırlanmışöznenin kurgularıdır. Özne kendi kalıp-sınırı (bedeni) dahil, dışarıda olan bütün dünyayı uzay, zaman ve nedensellik zincirinin bir parçası olacak şekilde algılar ve tasarlar. Janaway'e göre Schopenhauer'un düşüncelerinde bu nedensellik 
iki yönde önemlidir: "O yanlızca maddesel şeyler arasındaki bütün etkileşimleri yönetmekle kalmaz, aynı zamanda bu maddesel şeylere ilişkin kurgumuzdan da sorumludur" (Janaway, 2007, s.37). Özetle görünürde varolan her şey özsel bir gerçeklikten uzak, öznenin tasarımidir.

İsteme, Shopenhauer'un düşüncelerindeher şeyi kuşatıc kör bir tözü belirtmektedir. Bu tözün temelde tek bir ilkesi vardır, bu da varlığını devam ettirme isteğidir. İsteme varolan her şeyde görünüme gelir ve belli basamaklarda nesneleşir. Bu nedenle varlı̆̆ını devam ettirme isteği her varolanda için ortak bir dürtüdür. Schopenhauer'a göre bu aşkın öz, yaşama ilişkin tek gerçekliktir. İstemenin görüngüler dünyasına ait hiçbir ahlaki, sosyal ya da düşünsel değerle ilişkisi yoktur. O, kör bir dürtü olarak kendi gerçekliğini tüm varolanlar olarak açımlar.

İstemenin nesneleşmesinin çok sayıda ve belirli basamakları vardır. "İstemenin farklı basamaklardaki nesneleşmesine ait her bilgi, duyarlılık, sinirler, beyin, tıpkı organik yaşamın öteki parçaları gibi, istemenin nesneleşmesinin anlatımlarıdır." (Schopenhauer, 2009, s.123). Schopenhauer bu basamakları açiklarken, Platoncu idelere gönderme yapar. İdeler, kendilerini sayısız bireyde ve öğede açığa vurmaktadırlar. Bu bireylerin çokluğu ancak uzay ile zaman aracılığ Bireylerin varoluşu, varlığını sürdürüşü ve yok oluşu nedenselliğe yani, yeter sebep ilkesine bağlıdır.

Yeter sebep ilkesi, bütün sonlu olanlarm, bütün bireysel varliklarm en son ilkesidir. Bu ilke, bireyin bilgisine geldiği biçimiyle, tasarmm evrensel kalıbıdır. Öte yandan, Platoncu idea bu ilkenin altma girmez. Bu nedenle de ne çokluğu ne de değişimi vardır. Kendilerini onun içinde dile getiren bireyler sayısıdir, durmadan var olup, durmadan yok olurlar. Oysa ideler değisşimin ve nedenselliğin dı̧ıında kalır. Yeter sebep ilkesinin onunla ilişkisi yoktur. Öznenin bütün bilgisi, geldiğ $i$ kalp bu olduğundan ve öznenin kendisi de bir birey olduğundan, ideler onun bilgi alanmm iyice dışmda kalacaktır. Dolayıstyla, idealar ancak bilen öznenin bireyliğinin askrya alınmastyla bilginin nesnesi olabilirler (Schopenhauer, 2009, s.120).

Platon'un ide'si, kendinde şeyin yani istemenin upuygun nesneleşmesidir. Böyle düşünüldügünde ide, zorunlu olarak nesnedir. İde, istemenin upuygun nesnesi olarak aynı zamanda bir tasarımdır ve istemenin 
nesneleşmesinin en üst basamağıdır. Oysa istemenin kendisi bir tasarım değildir. İsteme ile idenin farkı da budur. İde'yi tek tek ve geçici varolanlarda çoğaltan yeter sebep ilkesidir. Tek tek bireyler görüngüler dünyasına ait bir "çokluğu" ifade ederken, ide birliktir.

Tek tek bireyler istemenin yeter sebep ilkesi doğrultusunda dolaylı nesnelleşmeleridir. Görüngüler dünyasına ait bu bireyler ile kendinde şey olarak istemenin arasında ideler durur. Schopenhauer'a (2009) göre, Platon ile Kant arasındaki büyük uzlaşmanın temeli de budur. Kısaca söylemek gerekirse, istemenin upuygun nesnesi ide iken; dolayll, bulanık nesneleşmiş hali çokluklar, bireyler, görüngülerdir. Schopenhauer'a (2009) göre, bireyler olarak kendi dışımızda varolanı bir gövde (beden) ve bu gövdeye bağımlı duyular aracılığıla algılamaktayız. Algılananlar ise bireyin tasarımları olan tek tek varolanlardır. Beden kendinde biricik olan ve istemenin dolaylı ve somut nesneleşmesidir. Bu haliyle de istemenin dolaylı nesneleri arasında bir nesnedir; uzay, zaman ve yeter sebep kalıplarıyla kuşatılmıştır. Bedenin, bu kalıpların dışında bir algılama biçimi yoktur. Yani bireyin algısı varolanı bir birlik olarak kavrayacak düzeyde değildir. Ezeli ve zaman dışı olan istemenin saf bilgisini ya da onun upuygun nesneleşmesi olan ideyi kavrayamaz. Sonuç olarak, idenin ya da istemenin kendisinin bilgisinin, uzay, zaman ve yeter sebep kalıplarına bağımlılığı yüzünden, bireyin bilme yetisinin dışında olduğunu söylemek mümkündür.

$\mathrm{Bu}$ noktaya kadar Schopenhauer, Kant'in kendinde şeyi ile isteme arasındaki kurduğu özdeşliği Kant çizgisinde sıkı bir şekilde takip etmiştir. Sonraki aşamada ise Kant'ın bilinemez olarak nitelediği kendinde şeyin (ya da istemenin) bilenebileceğinden söz etmiştir. Schopenhauer, saf istemenin ya da onun upuygun nesneleşmiş hali olan idenin bireylerde ortaya çıacak bilgisel bir dönüşüm ya da yükselmeyle bilinebileceğini ifade etmiştir. Birey, bu sayede, istemenin esaretinden kurtulmuş ve bilginin saf ve isteksiz öznesine dönüşmüştür. Yeter sebep kalıbını aşmış ve nesneler arasın daki ilişkinin durağan seyrine dalmıştır. Böylece ideler ya da istemenin kendisi saf öznede bilinir olmuştur (Schopenhauer, 2009, s.123 -124).

Bir kişi, usun gücüyle yükseltilerek şeyleri görme bakımmdan alışılagelen yolu bıraktr. Yeter sebep ilkesinin kalpları onu zorlasa bile, yalnzza nesnelerin birbiri ile ilişkisini izlemeye son verir. 
Şeylerin nerede, ne zaman, niçin olduğunu, onlarm nereye gittiğini göz önüne almayı bıraktr. İlişkilerin izini sürmenin en son amacı, her zaman kişinin kendi istemesiyle bir ilişki kurmasudır. Yalın biçimde, onlarm ne olduklarma bakar. Soyut düşüncelere, aklm kavramlarma, kendi bilincinin kullanmma izin vermez. Tersine usunun bütün gücünü algllamaya verir. Bir görünümü, bir ağacl, dik bir kayalı̆̆ı, bir yapryı ya da başka bir şeyi bütünüyle algılamaya dalar. Bütün bilincini, gerçekten varolan doğal bir nesnenin sessizce, derin derin düşünülmesiyle doldurur. Kişi kendini nesnede yitirir. Açıkçası kendi bireylĭğini, isteğini unutur; salt, saf özne olarak; nesnenin tertemiz bir aynası olarak varolmayı sürdürür. Öyle ki, sankialgulayan biri yoktur, yalnzza nesne vardır. Kişi, algilayan, algıdan ayıramaz, bundan böyle ikisi bir olur. Çünkü bütün bilinç bir tek duyusal resimle doldurulmuştur. Nesne, nesne dı̧̧ıdaki bütün ilişkilerin dışma çıma noktasma ulaşmışsa, özne de istemeyle tüm ilişkilerinin dışına çımııssa, bilinen artık bireysel bir şey değil bir ideadır, ezeli bir kaltptır. Bu ise istemenin doğrudan nesne olması halidir. Bu algıda kendinden geçen kişi, bu yüzden artık birey de değildir (Çünkü birey, böyle bir bilgide kendini yitirmiştir). $O$, saf, isteksiz, acısı, zamansız bilgi öznesidir (bilginin saf öznesidir) (Schopenhauer, 2009, s. 125).

Schopenhauer (2009), saf öznenin seyre dalışını türünün idesine dönüşmesi olarak ifade eder. Bu safözne için uzay, zamanın ya da nedenselliğin hiçbir önemi kalmamıştır. Tasarım olan dünyanın gerçek özünün upuygun nesnesi olan ideyle bir olan özne için artık 'özne - nesne' ikircikliği de ortadan kalkmıştır. İde özne ile nesneyi kendinde içermektedir. $\mathrm{Bu}$ birlik halinde, tasarım olarak dünya yerini isteme olarak dünyaya bırakmıştır. Bu da gerçekliğin upuygun görünümüdür.

Bir kişi, birey olmaktan bilginin saf öznesine dönüştüğünde artık dünyanın kendinde bir anlamı olmadığını fark eder. Uzay, zaman kalıplarıyla kuşatılmış dünyanın ve kendi içinde deviniminin özsel bir gerçeklikle ilişkili olmadığını bilmektedir. Schopenhauer'a (2009) göre, 
görüngüler dünyasına ait tek tek varolanlardaki anlam, onlarda içkin olan ide kadardır. ${ }^{1}$

İdeyi bilme konusu, görüngüler dünyasında tek tek varolanların algılayarak ulaşılacak bir şey değildir. Belli basamaklarda istemenin dolaylı nesnelleşmiş halleri olarak görünenler, bu nesnelere maruz kalan bireyde illüzyon ve tasarımlar olarak algılandıklarından, istemenin saf hali ya da onun upuygun nesneleşmesi olan idenin bilgisinden uzaktır. Bu anlamda ide ya da istemenin kendisi dışarıda varolan tek teklere ilişkin deneyimlerle anlaşılacak bir şey değildir. Birey zaten istemenin kendisidir. Schopenhauer'a (1958) göre, ide ya da isteme bilgisi için, bireyin (kendimizin) yine kendisine yönelmesi gerekmektir. Sonuç olarak, dışarıda varolanlardan açıç̧a kavrayamadığım özün bilgisi için, içsel bir yoldan söz etmek mümkündür.

İsteme, kör bir dürtü olarak, tek bir amacını gerçekleştirmek için sürekli iş başındadır. Burada istemenin bu tek amacının 'varlığını sürdürme isteği' olduğunu tekrar belirtmek gerekmektedir. Varolmak, yaşamak hatta ölmek bile bu amaca hizmet etmektedir. Amacın belli bir koşul için gerçekleştirilmiş olması, istemenin sürekli işleyişini durdurmaz. Bu nedenle istemenin amacına ereceği, son bir doyum anı söz konusu değildir. İstemenin bu işleyişi, sonsuza kadar kendini gerçekleştirmek için, devam eder. İstemenin kendi amacı gerçekleştirmesi yönündeki çabasına karşı çıkan engeller 'acı'nın sebebidir. İstemenin kendini gerçekleştirmesi ise sevinç ve mutluluğun ifadesidir. Bu nedenledir ki isten cin akıldışı sonsuz uğraşı karşısında, kalıcı bir mutlulukta söz konusu değildir. Amacı için uğraşı her seferinde bir hoşnutsuzluk üzerinden harekete geçmektedir. Hoşnutsuzluğun (istemenin bireylerde kendini gerçekleştirebilmesi anlamındaki eksikliğinin) kendisi acı ve ızdırap vericidir ancak bunun karşısında sonsal bir doyum, huzur ya da mutluluk da söz konusu değildir. İstemenin doyuma ulaştığı nokta, amacı için yeni

\footnotetext{
${ }^{1}$ Burada temel alınan Plato'nun ide düşüncesini Schopenhauer'ın kavrayış şeklidir. Bu anlamda düşünüldüğünde Platon'un kendisinin ideleriaçıklayışı farklılıklar bulunmaktadır. Örneğin görüngüler dünyasina ait şeylerin ideleri Platon'a göre yoktur. Ideler kavramsal olarak varolanlarla ilgili bir açıklamadır. Bununla birlikte Platon'a göre her kavramın da idesi olmamaktadır. Özetle tekrar etmek gerekirse bu çalışma içinde ide düşüncesi Schopenhauer'ın kavrayışı temel alınarak ele alınmış, Platon'un düşünceleriyle karşılaştırma yapılmamıştır.
} 
uğraşının acısının başlangıcıdır. Çatışma sürekli devam etmektedir. Schopenhauer'un felsefesi bu anlamıla çileci (asketik) düşünce biçimidir.

Kendisinin dolaylı nesnelleşmeleri olarak tek tek varolan her şey gibi, bireyler de (insanlar da) istemenin kör dürtüsünün esiridirler. Bu varolanların her birinin evrimsel dönüşümleri kendilerindeki varolma isteğine göre meydana gelmiştir. Örneğin insanın üreme, yemek yeme, nefes alma gibi temel yaşamsal mekanizmalarına hizmet eden organlar bile uzay, zaman ve nedensellik kalıpları içinde istemenin amacını gerçekleştirmek (varlığını sürdürmek) için evrimleşmiş durumdadır. Bütün türler varlıklarını sürdürmek isteğiyle evrimleşmişlerdir. Hiçbir türde varlığını sürdürmekle ilgili olmayan bir yapı yoktur. Bütün bu yapılar istemenin sonsuz amacına hizmet etmekte ve onun kölesi olmaktadır. Yaşamak ya da varlığını sürdürmek de istemenin acı ve ızdırap dolu kör dürtüsünün esareti demektir.

İstemeden ve onun kör amacından bütünüyle kurtulmak, bireyin ancak istemenin nesnelleşmesi olan bedeninden vazgeçmesiyle yani ölmesiyle mümkündür. Bu şekilde nedensellik zincirine bağımlı bir beden kalmayacağından istemenin kendi amacını gerçekleştirmek isteyeceği bir varlık alanı da söz konusu olamayacaktır. Diğer taraftan Schopenhauer sürekli olmasa bile, bir an için istemenin köleliğinden kurtulmanın olanağının, istemenin ve onun upuygun nesnelleşmesi olan idenin birlik halini kavrayabilecek bilince yükselmeyle mümkün olacağını ifade eder. İsteme olarak birey, kendine döner ve kendini ortadan kaldırırsa, Schopenhauer'un tanımıyla, "Mayanın Peçesi" 2 bir an için aralanır ve aşkınsal istemenin bir bütün olarak hakikatine ulaşlır. Böylece insan yaşarken de bir an için istemenin amacını gerçekleştirmek için dayattıklarından ve ızdırabından kurtulur. Safözneolarak insan, varlığın bir bütün olan halini seyre dalar, özgürleşir.

Schopenhauer istencin köleliğinden kurtularak özgürleşme olanağını sanatçıların (dehaların) ve azizlerin elde edebildiklerinden sözeder. Schopenhauer'a (2009) göre sanat, şeylerin değişmez özünü, yani ideleri yeter

\footnotetext{
2 "1813'te doktora söyleminin yayınlanmasından kısa bir süre sonra Schopenhauer Weimar'da onu Hint Felsefesi yazınıyla tanıştıran Oriental bilimci F. Mayer ile karşılaş̧ı. Ve yaşamı sonuna dek Doğu Felsefelerine ilgisini sürdürdü. Yaşlılığında Upanishandlarn metni üzerine meditasyonlar yaptı. Bu yüzden kendi tasarım olarak dünya kuramını Hint Maya öğretisiyle ilişkilendirmişse bu şaşırtıcı değildir" (Copleston, 1998, s.31).
} 
sebep ilkesinden bağımsız görme yoludur. Deha sanatçı da bu özü sanat yoluyla kavrayan kişidir. Tüm sanatlar istemenin upuygun nesneleşmiş halini kavranabilir kılarken, müziğin durumu farklıdır. Müzik idelerin değil, istemenin kendisinin kavranışını sağlamaktadır. Bu nedenle de diğer sanatlardan üstün bir konumdadır. Aziz (ermiş kişi) ise istemenin beden üzerindeki bütün baskılarından kurtulmak için, kendi bedeninin istençlerinden vazgeçer. Bedenin istençlerinden bütünüyle vazgeçmek, bedenin kendisinden vazgeçmek, yani ölmek anlamı taşıdığından, aziz bu vazgeçişi ilerletebildiği noktaya kadar götürür. Kendindeki saf özü arayan aziz, bedenin nedensellik zincirine mahkum güdülerinden kurtulmaya çalışır, yani yaşarken yaşamdan vazgeçer. Bir an için istemenin kuşatıa baskısı kırılır ve istemenin dolaysız nesneleşmiş hali olan ide, bir bütün olarak aziz tarafindan kavranır.

Çalışmanın kavramsal çerçevesi gereği bu aşamadan sonra, istemenin kuşatıcılığ 1 karşısında özgürleşme olanağı açısından azizin kavrayışı bir kenara birakılarak, müziğin bu bağlamdaki öneminden söz edilecektir. Ancak öncelikle özgürleşme kavramının Schopenhauer'un düşüncelerinde ne anlama geldiği ele alınmalıdır.

\section{Özgür Eylem, İrade}

Schopenhauer, özgürlük kavramını faklı türlere ayırmaktadır. Bu türler şöyle sıralanabilir:

a) Fiziksel özgürlük: Herhangi bir maddi engelin yokluğudur.

b) Entelektüel Özgürlük: İstemli ve istemsiz düşünme gücü.

c) Ahlaki Özgürlük: Özgür istenç kararı.

Fiziksel özgürlük tanımı varlıklar için istemenin karşısında bir engelin olmaması anlamını taşır. Bu bakımdan özgür eylem için hareket noktası istemedir. İsteme doğrultusunda hareket eden ya da davranan her şey özgürdür, yani özgürlük, kendi istencine uygun olma anlamı taşımaktadır. Fiziksel özgürlük kavramı, anlamını en çok canlı varlıkların eylemleri olarak bulmaktadır.

Schopenhauer (2000), fiziksel özgürlüğün tanımındaki gibi, kendi istediğini engelsizce yapabilme olanağ 1 karşısında "istencin kendisi özgür 
müdür?" sorusunu irdeler. İstemenin kendi başına özgür olup olmadığına bakıldığında, bir istemenin nedensellik bağıyla bağlı, kendinden daha öncevarolan başka istemelerle ilişkili olduğu anlaşılır. İsteme, edimlerinin önceki zincirini görmez. Sadece o anki isteminin bilincindedir. Bu nedenle de birey, istemeni özgür zannetmektedir. Oysa kör bir dürtü olan isteme tarafından kuşatılan zorunlu bir nedensellik zinciri özgür istemeyi engeller. Burada zorunlulukla nedensellik aynı içeriktedir. "Her nedenin sonucu zorunludur, her zorunluluk bir nedenin sonucudur" (Schopenhauer, 2000, s.18). Haliyle tasarımlar dünyasına ait kurgusal değerler dışında (ki bu değerlerin zaten hakikatin kendisiylebir alakası yoktur), özsel bir irade ya da ahlaktan söz etmekte mümkün değildir. Aynı şekilde özgür eylem de istemenin kuşatıcılığında söz konusu olamaz.

Schopenhauer, istemenin özgürlügü ya da gerçek anlamda bir özgür eylemin olanağını da yine isten cin köleliğinden kurtulma yoluyla açıklar. Burada kendi özününün bilincine varmış saf bilen özneye tekrar atıfta bulunur.Öz-bilince(iç-duyu) yükselmiş özne, tüm duygu ve arzuları istemenin dışavurumları olarak kavrayacak, haz ve acı arasın daki bütün duygulanımları da aynı şekilde değerlendirecektir.

Özgürlük kavramı Descartes'ın beden-ruh ikircikliği gibi ruha atfedilecek birşey de değildir. Schopenhauer'a göre zaten istemenin dolaylı nesneleşmesi olan beden dişında bir ruh söz konusu değildir. Benzer bir karşı duruşu Kant karşısın da da gösterir. Kant'a göre özgür eylem, irade ya da ahlak insanda akıl olduğu için vardır. Oysa Schopenhauer'a göre akıl, sadece ihtiyaçlarımızı nasıl karşılayacağımızı bize söyler. Akıl, ahlakla ilişkili değildir ve insan doğasının işleyişinin bir parçasıdır. Ahlak insanın karakterinin bir özelliğidir ve baştan bellidir. Karakter ise bize doğanın kattığı bir şeydir. Karakterimiz görüngüler dünyasına ait şeyler karşısında doğru ya da yanlış; iyi ya da kötü karar almamızı sağlar, ancak bu değerlerin hiçbiri özsel bir gerçeklikle ilişkili değildir. Tek tek şeylere ilişkin değerlerimiz bir kurgu, tasarımdır. Her bir kararımız bir n edensellik zincirinin sonucudur. Bu bakımdan Schopenhauer, tıpkı özgür irade gibi, sürekli bir ahlaklı bir eylemin de söz konusu olamayacağını söylemektedir. İstencin köleliğinden kurtulmak için ne yapılması gerekiyorsa, özgür bir eylem ve irade için de aynı şey söz konusu olmalıdır. $\mathrm{Bu}$ da ancak istencin nedensellik kalıbıyla dayattı̆̆ 1 kuşatıcı bakısını kırmakla söz konusu olur. Birey kendine dönüp, öz bilincini kazanarak 
bilginin saf öznesine dönüşür. Böylece ideyi ya da istemenin kendisini bir bütün olarak kavrar ve özgür kalır. Bu, istemenin dolaylı bir görünümü olan bedenin esaretinden kurtularak veya sanat yoluyla mümkündür. Bilginin saf öznesi olarak kendini bir an için özgür kılmayı başarabilenler de, aziz ve deha sanatçılardır. İşte bu aşamadan sonra Schopenhauer'un düşüncelerinde sanatın, özellikle de müziğin isteme karşısında nasıl bir özgürleşme olanağı sağladığından söz edilecektir.

\section{Schopenhauer'un Düşüncelerinde Sanatın ve Müziğin Yeri}

Schopenhauer, aşkınsal olanın bilinebilmesinin yollarından biri olarak sanattan söz etmektedir. Bütün ilişkilerin dışında olanla, dünyada gerçekten özlü olan tek şeyle, idealarla, kendinde şeyin, istemenin doğrudan, upuygun nesneleşmesiyle ilgili bilgi sanat aracılı̆̆ıyla kavranır ve bu da deha sanatçının işidir.

$O$, saf seyre dalış aracllğ̆ ile kavranan ezeli ideaları, dünyanın bütün görüngülerindeki özsel, yerleşik öğeyi yineler ya da yeniden yaratır. Sanat, ideanm içinde üretildiği gerece göre yontu, resim, şür ya da müzik olur. Onun tek kaynă̆g, idealarm bilgisidir; tek amacı bu bilginin iletilmesidir. Bilim en son amaca hiçbir zaman ulaşamaz, tam bir doyuma da eremez. Tersine, sanat her yerde amacna ermiştir. Çünkü o, seyre dalışın nesnesini dünyann gidişindeki akıştan kopartp alır, bu nesneyi önünde yalıtılmıs olarak tutar. Bu akmtıda küçücük bir şey olan bu bir tek şey, sanat için bütünün temsilcisine dönüşür, uzamla zamandaki sonsuz çokluğa eşdeğer olur. Böylece sanatbu özel şeyin üzerinde durur, zamantn çarkm durdurur (Schopenhauer, 2009, s.132).

İdeler nedensellikle ilişkisizdir ve sanat aracığıyla ve estetik bir seyre dalışla kavranır. Deha sanatçının bunu yapabilmek için doğal bir yetisi vardır. Dehanın yetisi görüngüler dünyasına ait tüm değer ve amaçları bir kenara bırakabilme becerisidir. Sanatçı, tasarım olarak dünyanın yerine, ide olarak dünyayı kavramak için nedensellik zincirini kırar, özgürleşir. Böylece bilmenin isteksiz, saf öznesine dönüşürler. Sanatçının bu deneyimi akılla kavranacak birşey değildir. Sanatçının yolu bu anlamda estetik bir deneyimi ifade etmektedir. 
Deha sanatçıyı estetik seyire çağıran, doğanın ken disidir. Sanatçıyı bilmenin saf öznesi olma yoluna çağıran hoş ve güzel nesnelerdir. Doğal güzellik, sanatçının bu sürecine dışsal bir yardımcıdır. Tıpkı Platon'un düşüncelerindeki gibi, tek tek olarak varolanlardaki güzelliği görmek, güzellik idesine giden yolun hareket noktasıdır. Schopenhaure'a (2009) göre, Bireyin durdurak bilmeyen istek, tutku ve kaygıları ona ıdırap verirken, doğaki güzellik onu bir an için yatıştırır, iyileştir.

Schopenhaure'a göre, sanat yapıtı aracılığıyla duyulan estetik haz ile doğrudan doğayı, yaşamı seyre dalmaktan sağlanan haz, birdir, aynıdır. "Sanat yapıtı, bu hazzın dayandığı bilgiyi kolaylaştırmanın bir aracıdır yalnızca. İdeyi bilen, gerçeği pek bilmeyen sanatçı, yapıtında saf ideyi yeniden üretmiştir, onu gerçekten soyutlamıştır. Sanatçı dünyayı onun gözleriyle görmemize izin verir." (Schopenhauer, 2009, s.144). Doğaya bakarak yaşanan estetik den eyimle birlikte sınırlar kalkar ve saf, isteksiz bilmenin seyrine dalınır. Artık Maya'nın peçesi aralanır ve mutluluğun ya da mutsuzluğun bir önemi kalmaz. Birey artık varolanı bir bütün olarak kavrayan özneye dönüşür. Saf bilmenin getirdiği kavrayışla birlikte, istemenin köleliğinden kurtulmuş, özgürleşmiş olunur. Dünyanın biricik gözüne dönüşerek, acılardan arınmış olunur.

Deha sanatçının eserleri, ideleri görünür kılmaktadır. Eren'egöreSchopenhauer (2018), her eserin de bu güce sahip olmadığından söz eder. Kimi eserler ideleri apaçık gösterirken, kimisi daha az göstermekte ya da hiç gösterememektedir. Bununla birlikte her sanat alanı da ideyi aynı şekilde göstermemekte, farklılıklar içermektedir. Farklı sanat alanları, farklı ideleri görünür kılmaktadır. Örneğin, mimari yerçekimi, birleşme, sertlik, katılık, taşın evrensel nitelikleri, istemenin ilk, en yalın, en eklemlenmemiş hallerini gösterirken; şiir, trajedi (Schopenhauer burada dram sanatından söz etmekte) gibi sanatlar yaşamsal değerlerin özlerine ilişkin idelere yönelmişlerdir.

Ancak müzik, Schopenhauer'a göre bütün diğer sanatlardan apayrı bir yerde durmaktadır. Bu bakımdan Schopenhauer'un düşüncelerinde müziğin yerinden ve özgürleşme olanağı olarak öneminden ayrıca söz etmek bir gerekliliktir. 


\section{Müzik}

Schopenhauer'a (2009) göre müzik, diğer sanatlardan ayrı bir şekilde ele alınması gereken bir sanattır. Müzik, görüngüler dünyasına ait şeylerin değişmez özleri olan idelerin bir görünümü değildir. Diğer sanatlar istemenin upuygun nesneleşmesi olan idelerin taklidi ya da yeniden üretimiyken, müzik çok daha derin bir sanattır. Bu nedenle insanların üzerindeki etkisi de çok güçlüdür. İnsanın bilincinin derinlerinde bütünüyle kavranılır. Green'e (1930) göre, diğer sanatlar da insanları etkilemektedir ancak, müzik hiçbir zaman doğrudan temsil edilemeyecek olanın (istemenin) kopyası olması bakımından etkisi çok daha farklıdır.

Sanat eserleri tek tek şeylerin canlandırılmasıyla, istemenin upuygun nesnesi olan idelerin kavranmasını sağlayan bir nesnelleştirmedir. Bütün sanatlar, idealar aracılığıyla istemeyi dolaylı olarak nesnelleştirmektedir. Yani sanat eseri idelerin taklidi, görünümüdür. Oysa müziğin idelerle bir ilişkisi yoktur. Bu nedenlegörüngüler dünyasından tamamen bağımsızdır ve onu görmezden gelir (2009: 196). Sanatlar, istemenin dolaysız nesnesi olan idelerin taklidiyken, müzik istemenin kendisinin kopyası, onun görünür halidir. Goehr'e (1996) göre Schopenhauer, tasarım olarak dünya olmasa bile müziğin bir şekilde olabileceğinden söz eder. Müzik diğer sanatlardan bu nedenle ayrılır. Müziğin insanlar üzerindeki etkisinin güçlü olmasının nedeni de budur. İsteme, hem idelerde hem de müzikte kendini dolaysız nesneleştirir. Bu nedenle müzik ile ide arasında bir benzerlik olmasa bile bir analoji söz konusudur. Müzik ile ide arasındaki bu birebir benzemezliğinin temel sebebi, müziğin dilinin bilinçsizce kavranılmasıdır. Bilinçli veya bilinçsizce kavranılan sanatlar arasındaki fark, Schopenhauer'a göre besteci ile diğer sanatçıların da ayrı değerlendirilmesine sebep olmaktadır. Besteci, bilinçsiz bir şekilde, kendi müziğine dünyanın özünü temsili eden bir form verir. Oysa ressam, heykeltraş, şair gibi diğer sanatçılar, sanatsal çalışmalarını yaparken, kısmen de olsa, görüngüler dünyasına ait olanların özündeki ezeli-ebedi formların yeniden üretildiğinin bilincindedirler. Bu nedenle, bestecinin eserinin metafiziksel karakteri, kendisi için bilinçsiz kalırken, diğer sanatçılar yaptıkları metafiziksel edimin bir tür farkındalığına sahiptirler.

Müziğin doğası görüngülerden bağımsızdır ve istemenin kendisinin ifadesidir. "Müzik, görünmeyen ama bize seslenen bu diri tin, dünyaya 
bir biçim vermek için, onun ete kemiğe bürünmesi için çalışır, yani dünyayı benzer bir örnekte canlandırmaya uğraşır... Böylece biz dünyayı "gövdeleşmiş müzik" diye adlandırabileceğimiz gibi "gövdeleşmiş isteme" diye de adlandırabiliriz" (Schopenhauer, 2009, s.202).

Müzik dünyanın içsel özünü seslerle, yetkin ve doğru bir anlatımla ifade etmektedir. Dünyanın özsel doğası üzerine upuygun bir yöntemle yaklaşmak, felsefenin yoludur. Müziğin görünür kıldığını, kavramlarla yeniden ele almak da mümkündür. Bu bakımdan müziğin bilinçsizce gerçekleştirdiği metafiziksel uğraşı, aslında gerçek felsefenin kendisidir. Yani müzik istemeyi görünür kıldıkça, bir yandan da bilmeden felsefe yapmaktadir.

Müziğin öznesi bir tasarım değildir. Bu nedenle tasarım için atfedilebilecek herhangi bir gerçekliği yoktur. Görüngüler dünyasına ait duygu ve değerlerden uzaktır. Doğası gereği hafif ve saçmanın karşısındadır ve ciddi bir yapıdadır. Müzik, bilinçli bir taklit de değildir, çünkü istemenin kendisi kavramlar aracıllğıyla bilinçli bir şekilde gösterilemez. İstemenin kendisinde uzak taklitçi müzikler bunu yapmaktadırlar. Bu tür müziklerden vazgeçilmelidir.

Müzik her yerde veherkes için evrensel bir dildir. Müziği ezgisi sevinç ve mutluluğu ifade eder çünkü isteme için asıl gerçeklik bunlardır. Ezgi, kalbe yönelmiştir ve akıl yürüterek kavranılmaz. Yani müziğin dili sezgisel bir kavrayış gerektirmektedir. Bu nedenle akılla tasarlan mış ya da ifade edilmiş müzik istemenin uygun ifadesi değildir. Bununla birlikte müziğin sözleri de, müziğin kendi özünü sınırlayan ya da yönlendiren bir yapıdadır. Bu da, müziğe dışsal bir etki demektir. Müzik güfteye (sözlere) ya da kendisine dışarıdan benimsetilen başka gerçekliklere benzer bir tabi oluş içinde bağlıdır, her ne kadar bu boyun eğiş o kadar kaçınılmaz olmasa da. O her şeyden evvel kendisini güfteye uydurmalıdır, her nekadar o buna kesinlikle muhtaç değilse ve aslında o olmaksızın çok daha özgürce hareket ederse de. Ne var ki müzik sadece her notasını güftenin sözcüklerinin uzunluk ve anlamına uydurmak değil, fakat aynı zamanda baştan sona güfte ile belli bir tutarlılık içerisinde olmak ve aynı şekilde dışarıdan benimsetilen diğer keyfi hedeflerin karakterini taşımak ve buna uygun olarak kilise, opera, bando, dans ve benzeri (türden şeylerin) müziği olmak zorundadır (Schopenhauer, 2012, s.50). 
Schopenhauer, müziğin doğasının sözlerle sınırlanması konusunda opera sanatını da eleştirmektedir. Opera saf bir müzik olmaktan çok etkisini farklı araç ve yöntemleri üst üste getirerek, estetik hazzı zorlayan ve dayatan bir eğlence ürünüdür. Oysa gerçek müzik eserleri duyarlı bir ruh, yoğunlaşma ve dağılmamış dikkat talep etmektedir. Ancak bu şekilde müziğin içinde, kişi kendini kaybedebilmektedir. Opera müziği ise abartıll, şatafatll, renkli ve gösterişli haliyle birlikte, bir de librettodaki olay örgüsünün müziğin sınırlandırılışı bakımından, derinliğini bütünüyle kaybetmiştir. Bu şekilde müzik özsel ve gizemli anlamını yitirmektedir.

Her ne kadar Schopenhauer sözlü müziğin, müziğin saf dilini engellediğini söylese de, sözcüklerle müziğin uyumlu bir hale gelebileceğinden de söz eder:

Müziğin sözcüklerle bağdaşttrlması ve uyumlu haligetirilmesi mümkündür. Hatta bu bağdaştırma ve uyarlama sezgisel kavrayş vasitastyla meydana getirilen bir olaylar dizisine kadar götürülebilir ve böylece bütünüyle işsiz güçsüz kalmaktan hazzetmeyen sezgisel biçimde kavrayp düşünen aklimı da kendine kolay ve paralel bir uğraş bulabilir. Bu suretle dikkat bile müzik üzerine daha să̆lam biçimde sabitleşir ve onu takip eder; ayn zamanda sezgisel kavrayışm bir resmi veya sureti, sözgelimi külli bir kavram için bir örneğe benzer bir model veya şema, tmilarm kalbe hitap eden evrensel dilleriyle söyledikleri şeye uyarlanır (Schopenhauer, 2012, s.52).

Schopenhauer, müziğin armonik ve melodik yapısıyla, doğa arasında bir analojiler kurar. Bu sayede müziğin, dünyanın ve doğanın özünü nasil ifade ettiğini belirtir.

Müzikte bas notalar inorganik doğayı, dünyanın kütlesini ifade etmektedir. $\mathrm{Bu}$ bakımdan bas notalar istemenin en alt basamaktaki nesneleşmesinin temsilidir. Armonideki alt sesleri olan baslar, armoni kuralları gereği, hep tiz bir notaya ya da nota gruba eşlik ederler, onlarla birlikte tınlarlar. Bas notalar melodinin gezin diği tiz notaların temelidir. Her bir tiz nota titreştiğinde, bir bas notayla rezonans olmaktadır. Bu da tüm doğadaki cisimlerin, organik varolanların dünyadan evrildiğinin ve gezegenin onlara kaynaklık ettiğinin ifadesidir.

Bas seslerin en alt smormm altmdaki ses duyulamaz. Bu, şu olguyla örtüşün Biçim ile nitelik olmaksızm hiçbir özdek algılanamaz. 
Yani, özdek, içinde bir ideanm kendini dile getirdiği, daha fazla açılanamayan bir güç ortaya çıkmadan algılanamaz. Daha genel olarak da hiçbir özdek büsbütün istemesiz olamaz. Dolayısıyla, nasll bir sesin entenasyonu notadan ayrlamyorsa, istemenin nesneleşmesinin bellibir basamağıda özdekten ayrlamaz (Schopenhauer, 2009, s.197).

Yüksek (tiz) notalar organik varolanları, yanibitki vehayvanları temsil ederler. Dizilerdeki farklı nota yükseklikleri istemenin farklı basamaklardaki nesnelleşmesinin ifadesidir.

Pes ya da tiz sesler oldukları halleriyle bir anlam sürekliliğine sahip değildir. Onların armoni kuralları gereği birbirleriyle ilişkilenmeleri de, görüngüler dünyasında varolan tek tek şeylerin yaşamı anlamlı bir bütün olarak görebilecek, tutarlı bir bilinçden eksik olmalarını imler. Tek tek varolanların hiçbiri kendi türü ile ilişki içindeyken bu bilince erişemez. Türüne ait katı kuralların koyduğu sınırlarla bilgisel bir dönüşüm söz konusu olamaz. Bu tıpkı tek tek seslerin, doğuşkanları gereği diğer seslerle kurduğu armonik ilişkiye benzemektedir.

Melodi, müzikte özgürleşme olanağıdır. Tutatlı ve bütüncül anlamıyla ilerleyen bir melodi, başlica duyulan bir ses dizimi olarak istemenin en yüksek düzeyde nesneleşmesinin temsilidir. Melodi insanın bilinçli yaşamını ve uğraşlarını ifade eder.

Ona (melodiye) us bağışlandı̆̆ için, yalnızca o kendi gerçekliğinin, sayısız olană̆̆m çı̆̆ırında hem önüne hem arkasıma bakar durur. Böylece yaşam çı̆ırmı bilinçle tamamlayarak onu anlamlı bir bütün yapar. Benzer biçimde yalnzza melodide baştan sona anlaml, yönelimsel bir bă̆ vardır. Böylece melodi, kendi üzerine düşünerek aydmlamıs istemenin öyküsünü söyler. Bu isteme art arda gelen eylemler olarak gerçekliğe kendi damgasm vurur. Ama melodi daha fazlasmı da söyler. Melodi istemenin gizli öyküsünü anlatır, onun her dürtüsünü her uğraşım, her heyecanını resmeder. Aklin geniş, olumsuz 'duygu' kavramı içinde topladı̆̆ her şeyi, aklm soyut kavramlarmm içine daha fazla almamayan her şeyi resmeder melodi (Schopenhauer, 2009, s.199).

Schopenhauer, melodilerin sonsuz çeşitliliğini doğadaki bireylerin, türlerin, tek tek varolanların ve onların yaşam biçimlerinin ve hallerinin sayısız çeşitliliğiyle ilişkilen dirmiştir. Hoşnut olma, mutluluk ya da sevinç 
istemenin doyumunun bir göstergesidir. Bununla birlikte mutluluk sürekli ve kesintisiz değildir. İstemenin doyuma ulaştığı an yani mutlu olma anı yeni bir istemeye hızlı bir geçişle kırılır. Yeni istemenin gerçekleşme çabası acı, can sıkıntısı ve bıkkınlık sebebidir. Buna benzer şekilde melodinin de yapısı temel tonaliteden sayısız farklı yollara sapma özelliğindedir. Bu anlamda sadece armonik aralıklara değil, tonalitenin diğer derecelerine de yönelme eğilimindedir.

Ağır melodiler, çarpıcı, sancll uyumsuzluklar, ana tona birçok ölçüden sonra geri dönme, gecikmiş, zor elde edilen doyumla koşut olarak üzüntülülür. İstemenin yeni uyarcasinn gecikmesinin, bıkkmlığın, uzaymp giden ana tondan başka anlatımıolamaz. Bunun etkisi çok geçmeden katlanlmaz olur. Pek tek düze olan, anlamsız melodiler bu etkiye yaklaşır. Hızlı dans müziğinin kısa, çekici tonlarn, kolay ulaşan olsa olsa stradan bir hazzı anlator gibidir. Öte yandan büyük evreleri, uzun pasajları, geniş kapsamh değişmeleriyle Allegro maestoso, uzak bir amaca sonunda erişmeye doğru, daha büyük, daha soylu bir çabayı imler. Adagio, bütün önemsiz doyumlara tepeden bakan, büyük, soylu bir çabanm çektiğgi üzüntüyü dile getirir. Minör ile majörün etkisi harikadır. Bir yarm tonun dönüşümü, majör yerine minör üçlünün ortaya çıkışı nasıl da şaşırtıcıdrr. Minördeki adagio en keskin acryı anlatmayı başarır, insan alt üst eden bir ağıta dönüşür. Minör tondaki dans müziğ $i$, erişilmeyen, küçümsenmesi gereken önemsiz doyumlarn gösterir gibidir (Schopenhauer, 2009, s.201).

Melodinin bu hareketliliği, onun doğasında içkin olan bir özelliğidir. Bütün bu dolanımlardan sonra melodi yine de asıl tona (tonic'e) dönmek istemektedir. Melodinin hareketliliği istemenin kendini gerçekleştirmek yani doyuma ulaşmak için uğraşının temsilidir. Asıl tona dönüş ise istemenin doyuma ulaştığı anı ifade eder. Melodinin yapısını öylece görebilmek, istemenin doğasını seyretmek gibidir. Deha besteci özgün melodiler bularak, istemenin insanın derinlerindeki gizil halini açığa çıkarır. Varlığın özsel yapısının bilgisini dile getirir. Bu dil bestecinin anlama yetisinin ve bilincinin üstünde bir yapıdadır. Besteci bunu, tıpkı hipnotize ya da uyku halindeki gibi, biliçsizce (belki de bilinçdışı demek uygun olur) gerçekleştirir. Bu nedenle deha bestecinin doğasının diğer sanatçılardan farklı olduğu söylenmelidir. 


\section{Sonuç}

Schopenhauer'da "isteme", varolan her şeyi kuşatan bir kör dürtü niteliğindedir. Bu dürtünün tek amacı varolmak, varlığını sürdürmektir. Görüngüler (fenomenal) olarak varolan her şey uzay, zaman ve yeter sebep (nedensellik) kalıplarıyla sınırlanmış bireyin kurgusu, tasarımıdır. Bireyin bu tasarımındaki temel ilkesi istemedir. Tek tek varolanlar istemenin belli basamaklardaki dolaylı nesneleşmesi olarak görünüme gelirler.

Platon'un "ide" düşüncesinde söz ettiği kavram, istemenin dolaysız nesnesi olan ve görüngüler dünyasın tek tek varolanların değişmez özüdür (ilk örneğidir). İdeler istemenin upuygun nesneleridir ve tek tekler dünyası karşısında varolanın birliğini ifade etmektedir.

İstemenin varlığını sürdürme dürtüsü hiç ara vermeyen sonsuz bir uğraş olarak ken dini açımlar. Varolan her şeyinde istemenin nesneleşmesi olduğu düşünüldüğünde, bu dürtü sürekli kendisini kendinde gerçekleştirmek ister. İsteme istediğini gerçekleştirdiği anda (doyuma ulaştı̆̆ı anda) yeni bir istemeyi açığa çıkarır. İstemenin bu doyumsuz doğası Schopenhauer'a göre huzursuzluk, acı ve ızdırap nedenidir.

Buna da "istemenin köleliğii" demek mümkündür.

İsteme bireylerde kendini beden olarak görünüme getirmiştir. Beden istemenin kendisi olarak, onun amacına tabidir. Bununla birlikte beden nedensellik zincirinin dışında varolmaz, yani bireyin isteme karşısındaki köleliğinin sebebi bedenidir. Bedeniyle sınırlanmış bireyin, istemenin köleliğinden sürekli anlamda bir kurtuluşu söz konusu olamaz. Bu ancak bedenden vazgeçmekle yani ölümle mümkün olmaktadır. Eğer istemenin köleliğinden kurtulmak, özgürleşmek ise Schopenhauer'a göre, bunun olanağ1 ancak ölümle sağlanabilmektedir. İstemenin amacının hiç bitmeyen acı ve ızdırap verici halinin karşısında intihar bir özgürleşme olanağıdır.

Schopenhauer, özgür eylem ya da iradenin, istemenin kendisinin özgür olabilmesiyle mümkün olabileceğinden söz eder. Nedensellikten bağımsız bir istemenin söz konusu olup olamayacağını sorgularvesürekli bir özgür iradenin söz konusu olamayacağından söz eder. Schopenhauer beden-ruh ikircikliğini de reddetmektedir. Ona göre ruh yoktur. Akıl ve zihin bedenin bir işlevinin sonucudur. Bu bakımdan insanda özgür eylem 
ya da iradeyi atfedecek beden dişında bir alan yoktur. Bununla birlikte bir an için de olsa istemenin köleliğin den kurtulmanın mümkün olduğunu da belirtir. Belli anlamdaki bir bilgisel yükselmeyle bu başarılabilir. İstemenin bir görünüşü olarak birey kendine döner. Kendinde, kendi gizil özünü fark eder. Perde aralanır ve birey bilmenin saf, isteksiz öznesine dönüşür. Böylece görüngüler dünyasına ait çokluktan kurtulan özne, varlığ 1 bir bütün olarak kavrar, onun seyrine dalar. Schopenhauer bunun çileci bir anlayışla bedenin isteklerinden olabildiğince vazgeçerek veya sanat yoluyla sağlanabileceğini belirtmektedir. Azizler (ermişler) ve deha sanatçılar da bu uğraşı başarabilenlerdir.

Sanat istemenin upuygun nesnesi olan idelerin temsilidir. Deha sanatç bilgisel bir yükselmeyle birlikte ideleri eserinde görünür kılar. Sanatın insanlar üzerindeki sezgisel etkisinin nedeni de varlı̆̆ın upuygun nesnesinin temsilinin gücüdür. Bu noktada bir an için zaman durur, görüngüler dünyasına ait hiçbir duygu ve değerin önemi kalmaz. Acı ve ızdırap son bulur ve idelerin bir bütün olarak estetik seyrine dalınır. İnsan bir an için de olsa özgürleşir.

Schopenhauer'un düşüncelerinde müziğin diğer sanatlardan ayrı bir konumu vardır. Müzik, diğer sanatlar gibi istemenin upuygun nesnesi olan idelerin temsili değil, istemenin kendisinin temsilidir. Yani istemenin temsil edilmesi bakımından ide ile müzik aynı düzeydedir. Deha besteci müziğinde bilinçsizce ve sezgisel olarak istemeyi görünür kılar. Diğer sanatçllar bilinçli bir yükselmeyle ideyi temsil ederken, besteci bilinçsizce istemenin kapısını aralar. Müziğin istemeyi dolaysızca temsil etmesi bakımından insanlar üzerindeki sezgisel etkisi diğer sanatlardan daha güçlüdür.

Armoni doğayı temsil eden seslerle istemenin farklı basamaktaki nesnelleşmelerini ifade eder. Besteci müziğindeki melodik yapıyla istemenin bitip tüken meyen uğraşını görünür kılar. Melodik değişim ve çeşitlilik istemenin doğasının dolaysız temsilidir. Bu bakımdan müzik aracılı̆̆ıyla istemenin köleliğinden kurtulmanın anahtarı melodinin seyridir. Melodi, Schopenhauer'a göre bir özgürleşme olanağıdır. Melodi istemenin aşkın doğasını apaçık temsil eder. Müziğin melodik yapısı sayesinde görüngüler dünyasının bütün kalıpları kırılır ve varlık bir bütün olarak görünümegelir. Müzik aracılığılla sezgisel olarak istemenin 
kendisini kavrayan insan, bir an için istemenin kuşatıcı baskısından kurtulur, acı ve ızdırabı son bulur. Böylece müzik aracılığıyla özgürleşmiş olur. 


\title{
EXTENDED ABSTRACT
}

\section{Music as a Possibility of Freedom in Schopenhauer's Thoughts}

\author{
R. Görkem Aytimur \\ Tokat Gaziosmanpaşa University
}

In this study, the possibility of free action through music was investigated in Schopenhauer's thoughts. In this context, first of all, the free will and the possibility of action in accordance with its have started to be studied by specifying the place in Schopenhauer's philosophy.

The basic approach of philosophy is "will", which is an ontological essence as well as an epistemological and moral principle. The possibility of free action or desire against the will, which is a blind impulse that encompasses everything, is stated in the context of Schopenhauer's ideas. Schopenhauer talked about the importance of music while talking about the possibility of freedom in the face of the will. In this respect, it is explain that, in Schopenhauer's thoughts, as aganist to the desire that is stated as an essence, how the possibility of free will is provided through music.

In Schopenhauer, the will is a blind impulse that encompasses everything that exists. The only purpose of this impulse is to exist and continue to exist. Everything that exists as phenomena is the design of the individual and confined to patterns of space, time and sufficient cause (causality). The basic principle in this design of the individual is the will. Individual ones appear as the indirect objectification of the will at certain levels.

The concept that Plato mentions in his "idea" thought is the invariant essence of the individual beings of the world of phenomena, the direct object of the will. The ideas are the proper objects of the will and express the unity of the existing against the world of individual.

The urge to survive reveals itself as an endless endeavor. Considering that there is objectification of the will in everything that exists, this impulse constantly wants to realize itself. It reveals a new request as soon as it realizes what it wants (when it reaches saturation). According to Schopenhauer, this insatiablenature of the will is thecause of restlessness, pain and anguish. It is possible to say this "slavery of the will". 
The will is made itself appear as a body in individuals. The body, as the will itself, is subject to the will's purpose. However, the body does not exist outside the chain of causality, that is to say, it is the cause of the individual's slavery against the will There can be no permanent liberation of the individual bounded by his body from the slavery of the will. This is only possible by giving up the body. that's means death. According to Schopenhauer, if it is to get rid of the slavery of the will, to be liberated, this can only be achieved by death. Suicide is a possibility of emancipation the never-ending pain and anguish of the goal of the will.

Schopenhauer mentions that free action or will is only possible if the will itself can be free. It asks whether there can be any will independent of causality and that there is no permanent free will. Schopenhauer also rejects body-spirit duality. According to him, there is no soul. Wisdom and mind are the result of a function of the body. In this respect, there is no space other than the body to attribute free action or will to man. However, he also states that it is possible to get rid of the slavery of the will for a moment. This can be achieved by a cognitive elevation in a certain sense. As an aspect of the will, the individual turns to himself. He realizes in himself his own hidden essence. The veil is spaced and the individual becomes a pure and reluctant subject of knowladge. Thus, the subject escaping from the multitude of phenomena grasps existence as a whole and dives into its course. Schopenhauer states that this can be achieved by giving up the desires of the body or possible through art.

Schopenhauer says that, artists (geniuses) and saints can to gain liberation from the slavery of the will.

In order to get rid of all the pressures of the desire on the body, the saint gives up the demands of his own body. As the meaning of giving up the demands of the body completely, giving up the body itself. The saint takes this renunciation to the point where it can advance. The saint, who seeks pure essence in himself, tries to get rid of the motives of the body condemned to the chain of causality, that is, he gives up life while he lives. For a moment the surrounding pressure of the will is broken and the idea, which is the direct objectification of the will, is grasped by the saint as a whole. 
Schopenhauer says that art as one of the ways understood to will as a whole. Information about what is outside all relationships, that is, the direct, appropriate objectification of the will, is understood through art, and that is the work of theartist. Art is therepresentation of ideas, which is the direct object of the will. The genius artist makes the ideas visible in his work with an cognitive ascent. Theintuitiveeffect of art on humans is also due to the power of representation of the proper object of being. At this point, time stops and no emotions and values belonging to the world of phenomena matter. The pain and suffering ends and the aesthetic course of the ideas as a whole is immersed. One gets free even for a moment.

However, according to Schopenhauer, music stands in a different place from all other arts. While all the arts make the direct objectification of the will understandable, the state of music is different. Music provides understanding of the will, not theideas itself. Therefore, it is superior to other arts. In this respect, it is necessary to mention the place of music and its importance as a possibility of emancipation in Schopenhauer's thoughts.

Music is not a view of the ideas, the invariant essences of things belonging to the world of phenomena. Music is a much deeper art, while other arts are imitation or reproduction of ideas, the direct objectification of the will. Therefore, the effect on people is very strong. It is fully understood in the depths of human consciousness. Ideas and music are at the same level in terms of representation of the will. Genius composer, makes visible to the will in his music unconsciously and in tuitively. The composer opens the door of the will unconsciously while other artists represent the ideas with a conscious ascension.

The harmony expresses the objectification of the different steps of the will with the sounds representing nature. The composer makes visible the endless endeavor of the will with the melodic structure in his music. Melodic change and diversity are direct representation of the nature of the will. In this respect, the key to getting rid of theslavery of the will through music is the course of the melody. According to Schopenhauer, the melody is a possibility of emancipation. The melody clearly represents the transcendental nature of the will. Thanks to the melodic structure of music, all the patterns of the world of phenomena are broken and the entity appears as a whole. The person who in tuitively grasps to natureof thewill 
through music, gets rid of the surrounding pressure of the will for a moment and ends the pain and anguish. Thus, it is liberated through music.

\section{Kaynakça / References}

Aktaş, A. O. (2012). Hayatı müzikle anlamak ve Schopenhauer felsefesinde müzik. Doğu Batı, 62, 43 - 70.

Eren, I. (2018). Arthur Schopenhauer'a göre dünyayı sanatla anlamak. Kayģ, 30, 93-102.

Goehr, $L$ (2007). Schopenhauer and the musicians: an inquiry into the sounds of silence and the limits of philosophizing about music. D. Jacquette (Der.), Schopenhauer, philosophy, and the arts içinde (ss.200-228). New York: Cambridge University Press.

Green, L. D. (1930). Schopenhauer and music. The Musical Quarterly, 16, 199206.

Pothast, U. (2008) The metaphysical vision: Arthur Schopenhauer's phllosophy of art and life and Samuel Beckett's own way to make use of it. New York: Peter Lang Publishing,

Schopenhauer, A. (1969). The world as will and representation, volume 1. (E. F. J. Payne, Trans.). New York: Dover Publications, Inc.

Schopenhauer, A. (1969). The world as will and representation, volume 2. (E. F. J. Payne, Trans.). New York: Dover Publications, Inc.

Schopenhauer, A. (2000). İstencin özgürlüğ̈̈̈ üzerine. (M. Söyler, Çev.). Ankara: Öteki.

Schopenhauer, A. (2009). İsteme ve tasarm olarak dünya. (L. Özşar, Çev.). İstanbul:Biblos Kitabevi.Schopenhauer, A. (2010). Güzelliğin metafiziği. (A. Aydoğan, Çev.). Ankara: Say Yayınları.

\section{Kay nakça Bilgisi / Citation Information}

Aytimur, R. G. (2019). Schopenhauer'un düşüncelerinde bir özgürleşme olanağı olarak müzik. OPUS-Uluslararası Toplum Araştırmaları Dergisi,13(19), 2176-2199. DOI: 10.26466/opus.574104 